\title{
EXPERIMENTAL STUDY OF THE AMOUNT OF ICE MELT USING THREE DIFFERENT METHODS: A CONTRIBUTION TO THE INTERNATIONAL HYDROLOGICAL DECADE
}

\author{
By Gerd Wendler and N. Ishikawa* \\ (Geophysical Institute, University of Alaska, Fairbanks, Alaska 9970 , U.S.A.)
}

\begin{abstract}
In the summer of 1972 , the amount of ice melt obtained by stake measurements on the McCall Glacier, Brooks Range, was compared with the discharge of a small controlled run-off site, and with heat balance calculations. For daily values the agreement was not always good; however, for the i I d period for which the study was carried out, the agreement can be considered as excellent. The amount of ice melt calculated from run-off and heat balance gave 3.5 and $1.2 \%$ higher values, respectively, than the direct measurements. This is encouraging, insofar as it suggests that it may be possible to calculate the combined ice, water, and heat balance for the glacier as a whole.

RÉsumÉ. Etude expérimentale de la fusion d'un glacier par trois méthodes différentes. Pendant l'été 1972, on a comparé la fusion obtenue par des mesures de perches d'ablation sur le McCall Glacier, Brooks Range, les débits d'un petit bassin versant contrôlé et des calculs de bilans thermiques. Pour des valeurs journalières, la concordance n'était pas toujours bonne; cependant pour les i i jours qu'a duré l'étude la concordance peut être considérée comme excellente. Les fusions calculées à partir de l'écoulement et du bilan thermique ont donné des valeurs respectivement 3,5 et $1,2 \%$ plus fortes que celles mesurées directement. Ceci est encourageant dans la mesure où on peut en inférer qu'il est possible de calculer le bilan combiné glace, eau, chaleur, pour l'ensemble du glacier.
\end{abstract}

Zusammenfassung. Experimentelle Bestimmung der Eisablation mit drei verschiedenen Methoden. Im Sommer 1972 wurde am McCall Glacier in der Brooks Range die an Pegeln gemessene Eisablation mit dem Abfluss eines kleinen Testgebietes und mit Berechnungen des Wärmehaushaltes verglichen. Die Tageswerte stimmten nicht immer gut überein; doch kann die Übereinstimmung für die Periode von I I Tagen, über die sich die Untersuchung erstreckte, als ausgezeichnet betrachtet werden. Die aus Abfluss und Wärmehaushalt berechnete Eisabschmelzung war um $3,5 \%$ bzw. $1,2 \%$ höher als die direkt gemessene. Dies ist insofern ermutigend, als es die Berechnung des kombinierten Eis-, Wasser- und Wärmehaushaltes für den Gletscher als ganzes möglich erscheinen lässt.

\section{INTRODUCTION}

This study is part of a combined heat, ice, and water balance study being carried out on McCall Glacier, Alaska (Fig. I), as part of the International Hydrological Decade (I.H.D.). During mid-summer of 1972 , the ice ablation obtained from stake measurements was compared with the amount of ice melt measured from a small, controlled run-off site and with the amount calculated from consideration of the heat balance. The purpose of this study is to show the extent of agreement among these three methods in calculating ice ablation under simplified conditions, before integration over the whole glacier surface is attempted.

McCall Glacier (lat. $69^{\circ} 18^{\prime}$ N., long. $143^{\circ} 48^{\prime}$ W.) lies in the eastern and highest part of the Brooks Range (Romanzof Mountains), and is the only Arctic glacier currently being studied in the United States of America. It is of special importance as it lies on two glacier "chains" recommended for intensive study by the I.H.D., those of the Arctic Circle and Western America. The glacier has an area of $6.22 \mathrm{~km}^{2}$, which places it among the larger ones in the Brooks Range; it stretches from the snout at I $340 \mathrm{~m}$ to Mt Hubley at $2720 \mathrm{~m}$.

The McCall Glacier was studied during the I.G.Y. (e.g. Keeler, I957; Orvig, 196r, p. I-30; Orvig and Mason, I963), and our measurements commenced in r 969 . The results of the mass and water balance calculations for 1969 and 1970 have been presented previously (Wendler and others, 1972, in press).

Long-term climatic data for this area cannot be given, as no observations have ever been carried out for any extended time in the higher parts of the Brooks Range. The Brooks Range represents the climatic divide between the continental climate of central Alaska and the Arctic climate of the north slope (Searby, I968).

* N. Ishikawa is on leave from the Institute of Low Temperature Science, Hokkaido University, Sapporo, Japan. 


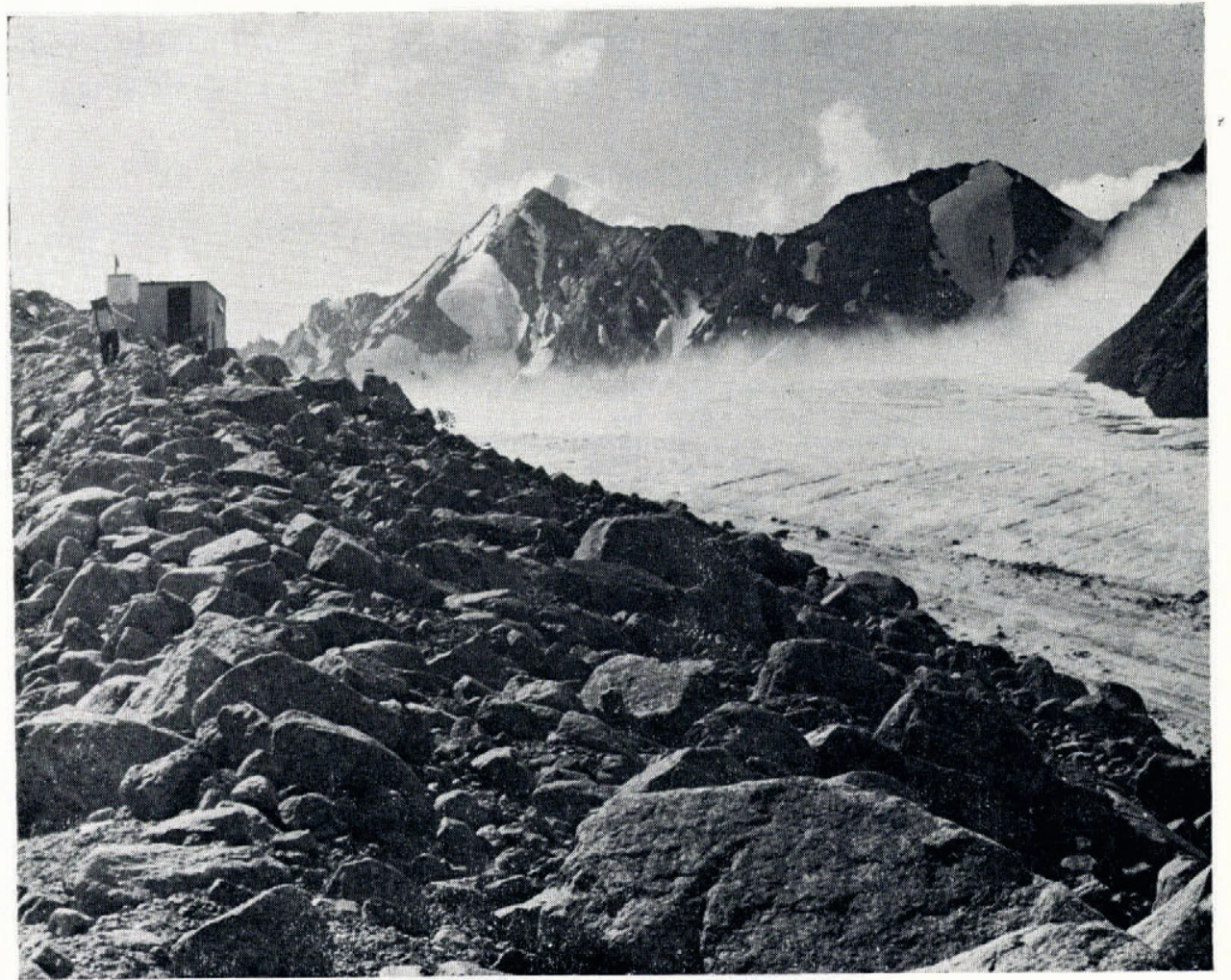

Fig. I. A view from the easterly moraine over the McCall Glacier. In the background Mt McCall. Photograph by L. Snyder.

\section{THE PERIOD OF OBSERVATION AND INSTRUMENTATION}

The period of good observational data extends from $9 \mathrm{~h}$ on $2 \mathrm{I}$ July to $9 \mathrm{~h}$ on I August 1972, a duration of I I complete days. The measurements were made on the glacier tongue at a height of $1730 \mathrm{~m}$, somewhat on the east side of the glacier (see Fig. 2). The study site consists of fairly smooth and uniform glacier ice, exposed $7^{\circ}$ to the north. This is also the general exposure of the glacier.

A small controlled run-off $\left(84.1 \mathrm{~m}^{2}\right)$ (Lang, I968; Derikx, in press) was established by putting insulating material (white parachute cloth) around the area of interest. The insulated glacier surface became raised relative to the adjacent surface and, in this way, after several days, a small ice dike was formed, surrounding the run-off area. Tests with dye were carried out twice during the period and these showed that no water flowed into or out of the controlled area, other than at the run-off channel at the lowest part of the controlled area. The water was collected in a hole which was cut by a chain saw into the ice, and was siphoned with a 2 inch $(5 \mathrm{~cm})$ diameter hose into a stilling well (Fig. 3). Originally, we tried to channel the water directly into the stilling well, but were unable to keep the channel from the ice to the stilling well water-tight for any extended time. Tests with dye showed that no water drained between the crystals from the hole in which it was collected. This could be expected, as the ice temperature was below the freezing point, and, furthermore, the hole was sheltered against direct solar radiation by a piece of plywood to prevent internal melting.

The stilling well had to be placed on a stable platform. Three stakes were drilled into the ice to a depth of more than $2 \mathrm{~m}$. After these stakes had frozen in, a piece of plywood was 
nailed onto them, on which the stilling well was placed. The water height was recorded using a Stevens recorder with a daily chart. Calibration measurements were made frequently by measuring the time required to fill a 21 calibration cylinder.

Ablation measurements were made with ten thin ( $5 \mathrm{~mm}$ diameter) ablation stakes, which were placed in the controlled run-off area. They were read twice daily.

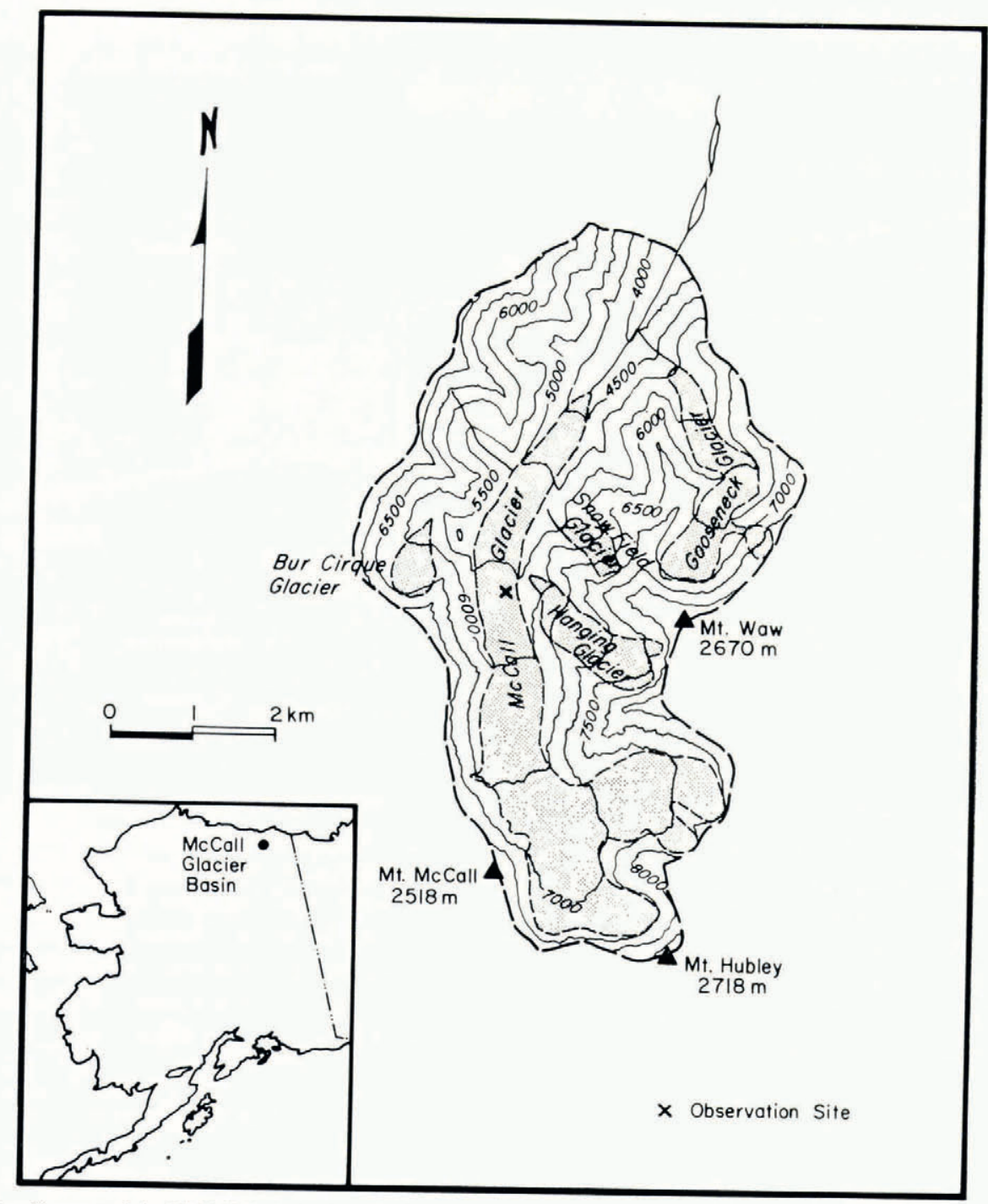
Fig. 2. Locality map of the McCall Creek basin. Shading represents glacier-covered area; note that the altitude contours are given
in feet.

The radiation was measured with a $\mathrm{PD}-4$ Davos radiometer. This instrument has four domes, two looking upwards and two downwards, two of them (glass) measuring the incoming and outgoing short-wave radiation, the other two ("lupolen") measuring the incoming and outgoing all-wave radiation. The output of these four channels, the instrument temperature, and the zero point were continuously recorded on a six-channel Siemens recorder. This 
instrument was calibrated against a sub-standard Linke-Feussner actinometer, built by Kipp en Zonen, Delft, Holland.

Temperature, humidity and wind speed were originally measured at four heights $(0.5, \mathrm{I}$, 2 and $4 \mathrm{~m}$ ) continuously. However, owing to a failure in an amplifier, this instrumentation stopped working at the beginning of the period. Therefore, the data from the more primitive back-up instruments had to be used. Thermohydrographs, which were calibrated with an Assman psychrometer, were placed at two heights $(150 \mathrm{~cm}$ and $10 \mathrm{~cm})$, and the wind velocity was continuously recorded with a mechanical anemometer system (Lambrecht).

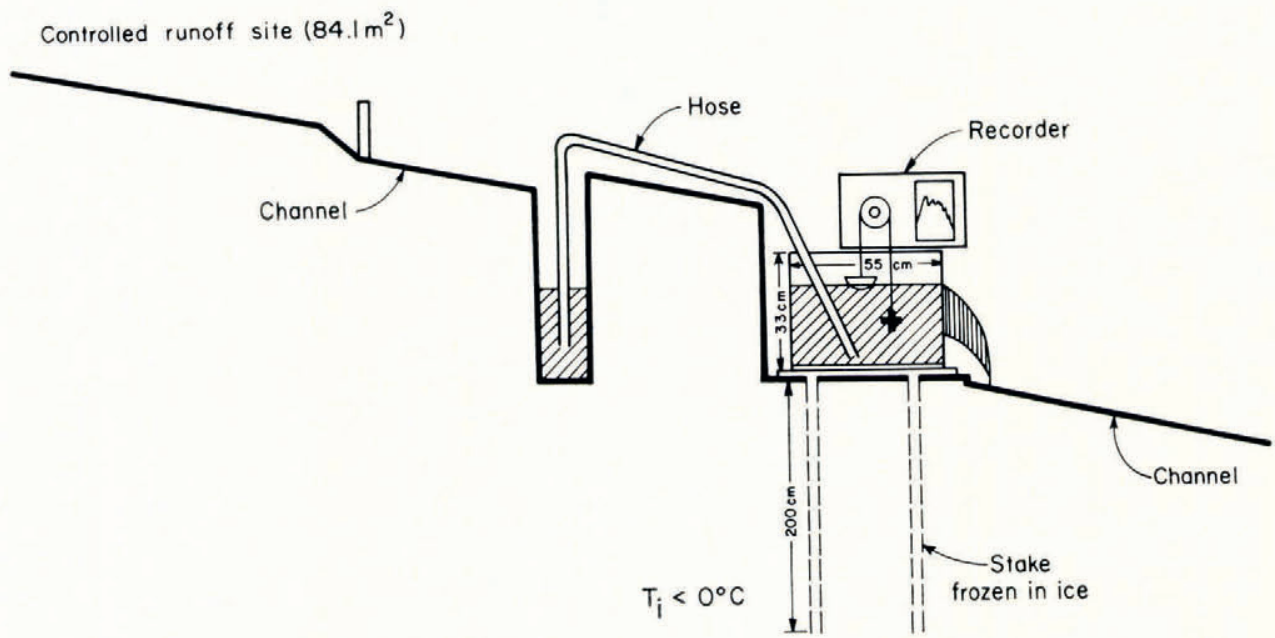

Fig. 3. Schematic drawing (vertical view) of the controlled run-off installation.

\section{Meteorological CONDitions DURING THE PERIOD OF OBSERVATIONS}

The mean and extreme conditions observed during the period are shown in Table I and the mean daily data in Fig. 4. It is not possible to compare these values with long-term means. as they are not known. However, a comparison with the four summers (I969 to i972) for which data are available, indicates that the temperature, water vapor pressure and ice ablation were somewhat above normal, while cloudiness and wind speed were below normal. Also the precipitation, $5.1 \mathrm{~mm}$ for the i $\mathrm{d}$ d period, was below the average. The association of the mean daily ablation with the climatic elements can be seen in Figure 4 .

Table I. Mean and extreme meteorological data, McCall Glacier 21 July-1 August 1972

\section{Element}

Screen temperature at $1.5 \mathrm{~m}\left({ }^{\circ} \mathrm{C}\right)$

Screen water-vapor pressure (mbar)

Cloudiness (Ioths)

Wind-speed at $2.4 \mathrm{~m}\left(\mathrm{~m} \mathrm{~s}^{-1}\right)$

Ablation daily ( $\mathrm{mm}$ water equivalent)

Net radiation $\left(\mathrm{Ly} \mathrm{d}^{-1}\right)$

$$
\left(\mathrm{MJ} \mathrm{m}^{-2} \mathrm{~d}^{-1}\right)
$$

$\begin{array}{ccc}\text { Maximum } & \text { Minimum } & \begin{array}{c}\text { Mean } \\ \text { (1 I d) }\end{array} \\ 7.6 & - \text { o.6 } & 3.5 \\ 8.49 & 2.53 & 6.20 \\ 10 & 00 & 5.2 \\ 6.6 & 0.5 & 3.1 \\ 56.6^{*} & 18.4^{*} & 30.4 \\ 208^{*} & 116^{*} & 156 \\ 8.7^{*} & 4.9^{*} & 6.5\end{array}$

* These values are daily extremes, while for the other climatic elements hourly extremes are given. 

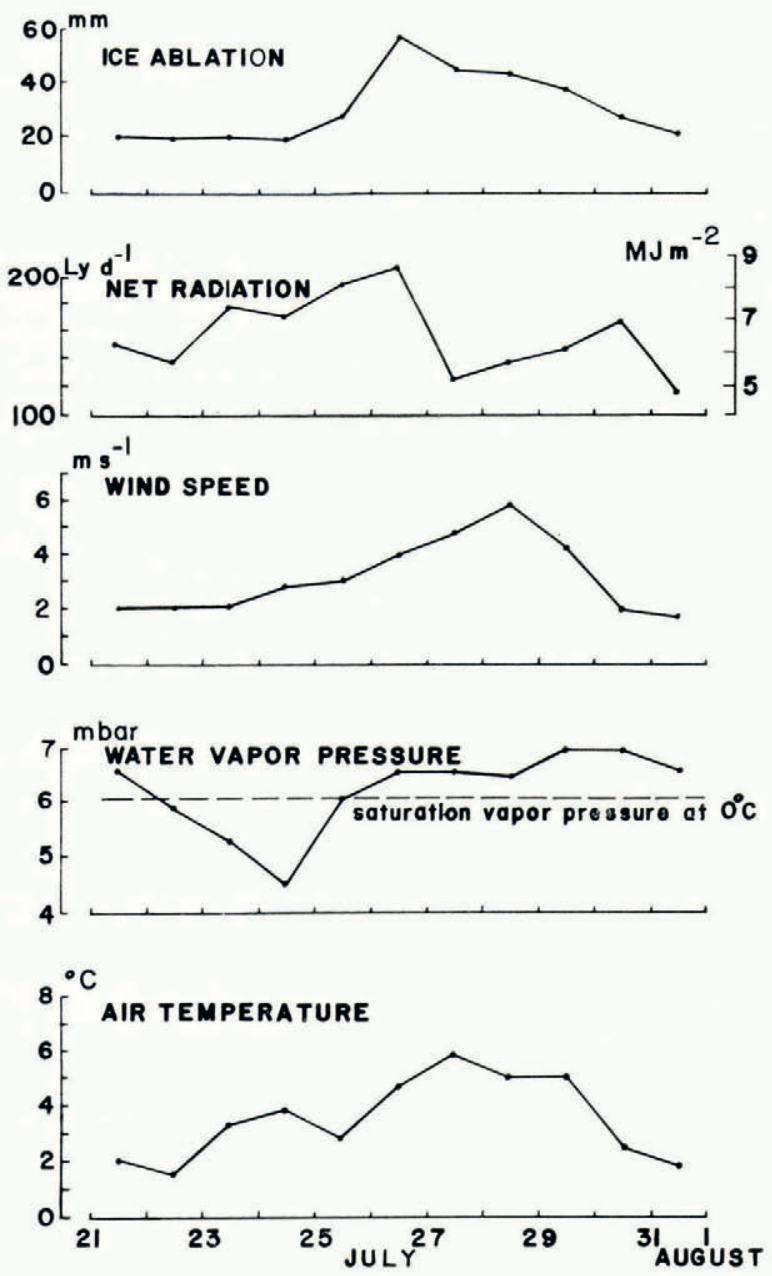

Fig. 4. Variations in mean daily values of meteorological elements, McCall Glacier, 1972.

\section{RESUlTS OF DIRECT STAKE MEASUREMENTS}

Ten ablation stakes were distributed evenly in the small controlled run-off area $\left(84 . \mathrm{I} \mathrm{m}^{2}\right)$. They were read twice daily to the nearest millimeter. The daily mean values can be seen in Figure 4, and in Table II the mean amount of the ablation of the ten stakes is given for the day, night, and $24 \mathrm{~h}$ periods for the whole period and the average day. Furthermore, the mean deviation between the stakes is given. It can be seen that the percentage deviation is smaller for day than for night values, while the absolute deviation has the opposite trend. This is understandable, as the ablation at night is only about a third of that of the daytime, so that small inaccuracies in the readings are more important for the night period.

Table II. Ablation in mm ice

$\begin{array}{lccc} & \text { Day } & \text { Night } & \text { Day and night } \\ \text { Sum (1 d) } & 243.5 \pm 17.2 & 88 . \mathrm{I} \pm \mathrm{I} 1.7 & 33 \mathrm{I} .6 \pm 20.9 \\ \text { Daily mean } & 22.1 \pm 7.1 \% & 8.0 \pm 13.5 \% & 30.1 \pm 6.3 \%\end{array}$


The data show that the deviations from the mean are not very large, which would also indicate a fairly uniform ice surface. However, if specific dates are compared, the deviation becomes much greater. Therefore, it seems to be advantageous to compare not individual days, but rather periods of several days' duration.

\section{RESUlts OF RUN-OFF MEASUREMENTS}

Characteristics of glacier run-off have been described previously (e.g. Meier and Tangborn, I96I). In our case the relationship between the water level in the stilling well and the amount of run-off was well established (Fig. 5). Using this calibration curve, the water-level heights could be converted into discharge measurements. The diurnal variation (Fig. 6) showed its

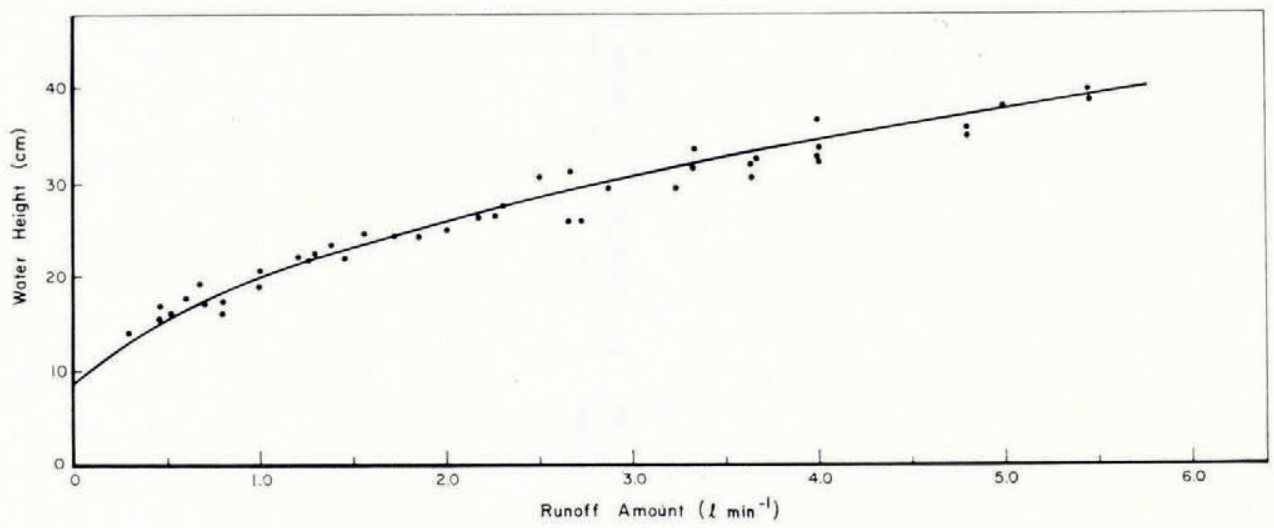

Fig. 5. The water-level-run-off calibration curve, McCall Glacier, 1972.

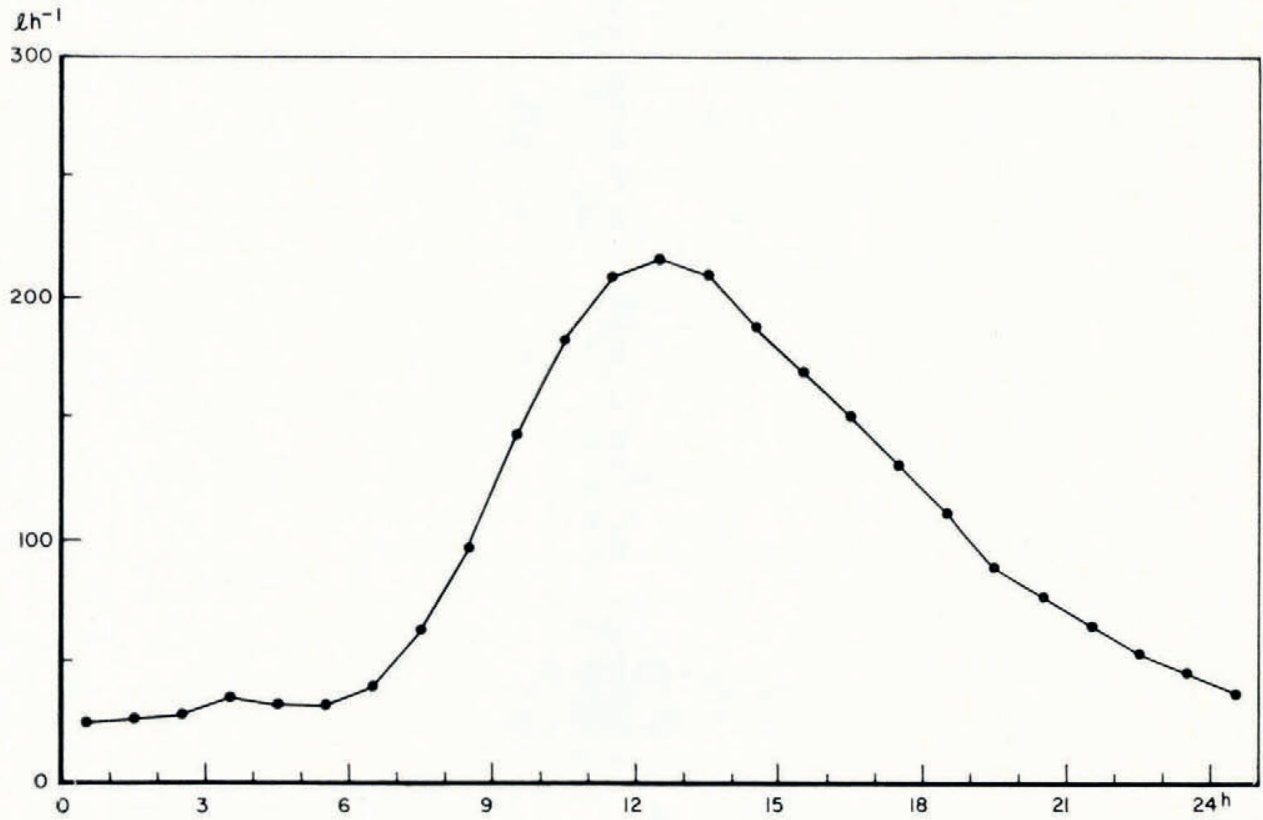

Fig. 6. Mean diurnal variation of run-off after correcting for precipitation, McCall Glacier, 1972. 
maximum at $12.30 \mathrm{~h}$, about half an hour after the maximum in radiation and before the temperature maximum. It is understandable that the time lag for this controlled area is small, due to its size. A comparison between a recording precipitation gage and the waterlevel receiver showed a shift in the maximum of $\mathrm{I}_{5}$ to $30 \mathrm{~min}$.

If one deducts the amount of water which discharged from the controlled run-off site due to rain, the amount of discharge owing to melting can be calculated (Table III).

- Table III. Amount of ice melt in mm water equivalent FROM RUN-OFF MEASUREMENTS

$\begin{array}{lccc} & \begin{array}{c}\text { Day } \\ (\mathrm{og} \mathrm{h}-2 \mathrm{O} \mathrm{h})\end{array} & \begin{array}{c}\text { Night } \\ (2 \mathrm{O} \mathrm{h}-\mathrm{Og} \mathrm{h})\end{array} & \begin{array}{c}\text { Day and Night } \\ (\mathrm{og} \mathrm{h}-\mathrm{Og} \mathrm{h})\end{array} \\ \text { Whole period } & 235.6 & 75.7 & 3 \mathrm{I} .2 \\ \text { Mean daily } & 2 \mathrm{I} .4 & 6.9 & 28.3 \\ \text { Maximum } & 36.4 & 12.9 & 45.7 \\ \text { Minimum } & 15.4 & 1 . \mathrm{I} & 18.8\end{array}$

\section{Results of heAt-BALANCE GALCULATions}

The heat fluxes at the glacier surface were calculated for hourly values and summed for half-day periods $\left(9^{-20}\right.$ and $\left.20-9 \mathrm{~h}\right)$. The following fluxes can be distinguished:

(a) radiation balance,

(b) sensible and latent heat,

(c) heat flux in the ice and amount of ice melt.

All fluxes towards the surface were considered to be positive, while those away from the surface were considered to be negative.

\section{(a) Radiation balance}

The mean and extreme daily values of the radiative fluxes are given in Table IV. The albedo was found to be $35 \%$, which is in good agreement with Dirmhirn and Trojer (1955). This value is higher than for pure ice, as the direct solar radiation caused internal ablation, and the glacier surface frequently had a rather white appearance (Yosida, I96o). The value

Table IV. Radiative fluxes, McCall Glacier, 2 I July-i August 1972

Short-wave incoming

Short-wave outgoing

Short-wave balance

Long-wave balance

Balance integrated over all wavelengths

Albedo

\begin{tabular}{cc}
\multicolumn{2}{c}{ Average } \\
$\mathrm{Ly} \mathrm{d}^{-1}$ & $\mathrm{MJ} \mathrm{m}^{-2} \mathrm{~d}^{-1}$ \\
$378 . \mathrm{I}$ & $\mathrm{I} 5.8$ \\
$13 \mathrm{I} .6$ & 5.5 \\
246.5 & $\mathrm{I} 0.3$ \\
-90.3 & -3.8 \\
156.2 & 6.5 \\
& \\
$34.8 \%$ &
\end{tabular}

\begin{tabular}{cc}
\multicolumn{2}{c}{ Maximum } \\
$\mathrm{Ly} \mathrm{d}^{-1}$ & $\mathrm{MJ} \mathrm{m}^{-2} \mathrm{~d}^{-1}$ \\
566.8 & 23.7 \\
$\mathrm{I} 97.7$ & 8.3 \\
369.1 & 15.4 \\
$-193.4^{*}$ & $-8.1^{*}$ \\
207.6 & 8.7
\end{tabular}

$44.0 \%$

\begin{tabular}{lc}
\multicolumn{3}{c}{ Minimum } \\
Ly d $^{-1}$ & $\mathrm{MJ} \mathrm{m}^{-2} \mathrm{~d}^{-1}$ \\
188.6 & 7.9 \\
56.1 & 2.3 \\
132.5 & 5.5 \\
$-17.0^{*}$ & $-0.7^{*}$ \\
115.5 & 4.8
\end{tabular}

$27.9 \%$

* The highest absolute magnitude was considered as maximum.

of the incoming short-wave radiation $\left(378 \mathrm{Ly} \mathrm{d}^{-1}\right)$ might be somewhat above the normal as the cloudiness was below the average. Owing to the lower amount of cloudiness, the longwave radiation budget $\left(-90 \mathrm{Ly} \mathrm{d}^{-\mathrm{I}}\right)$ is somewhat more negative than normal, but the radiation balance integrated over all wavelengths $\left(156 \mathrm{Ly} \mathrm{d}^{-1}\right)$ is somewhat higher than the average for mid-summer in the Brooks Range. 


\section{(b) The sensible and latent heat fluxes}

These fluxes were calculated using Prandtl's relation (Prandtl, I956; Lettau, I939, I949). However, as the measuring apparatus was not in working condition, a roughness parameter of $0.25 \mathrm{~cm}$ was assumed. This value was obtained for a period prior to the measurements described here, when the wind measurement system was still working. The surface conditions were similar for this period and the above-mentioned mean value was found for adiabatic or near adiabatic conditions. This roughness parameter is in agreement with other investigators (e.g. Hoinkes, I953; Untersteiner, 1957). Using the above value for $z_{0}$, the friction velocity, $u_{*}$ could be determined from

$$
\bar{u}_{z}=\frac{u_{*}}{k} \ln \frac{z-z_{0}}{z_{0}}
$$

with $k=0.4$ (von Kármán constant), $\bar{u}_{z}$ is the mean wind speed at height $z$, and $z$ the height. Values for $u_{*}$ between $3.6 \mathrm{~cm} \mathrm{~s}^{-1}$ and $46.8 \mathrm{~cm} \mathrm{~s}^{-1}$ with a mean of $17.8 \mathrm{~cm} \mathrm{~s}^{-1}$ were found.

The Austausch coefficient, $A_{\mathrm{a}}$, may then be obtained from the relation

$$
A_{\mathrm{a}}=\rho u_{*} k\left(z+z_{0}\right) \text {, }
$$

with $\rho$ the density of air. A correction for non-adibatic conditions was made using $A=A_{\mathrm{a}} /(\mathrm{I}+x)^{2}$, with $A$ being the Austausch coefficient for non-adiabatic conditions and $x$ a stability criterion, similar to the Richardson number, where

$$
x=\frac{g k^{2}\left(z+z_{0}\right)^{2}}{T u_{*}^{2}} \frac{\mathrm{d} \theta}{\mathrm{d} z} .
$$

A series of temperature profile measurements, carried out before the time of data analyzed here, showed that the temperature followed a near logarithmic distribution in the lowest $2 \mathrm{~m}$. A mean value of $z_{0}{ }^{\star}$ observed from the temperature was found to be $0.0056 \mathrm{~cm}$ for melting conditions and with the assumption that the surface temperature is $0^{\circ} \mathrm{C}$. This value is smaller than the roughness parameter which is to be expected, and has been found previously (e.g. Sverdrup, I936; Ambach, I963; Holmgren, I971).

For a logarithmic temperature and water-vapor distribution, the sensible and latent heat fluxes $S$ and $L$ are given by

$$
S=c_{p} A \frac{\mathrm{d} T}{\mathrm{~d} z} t \quad \text { and } \quad L=600 A \frac{0.623}{p} \frac{\mathrm{d} e}{\mathrm{~d} z} t
$$

where $c_{p}$ is the specific heat of air, $T$ the absolute temperature, $p$ the atmospheric pressure, $e$ the water vapor pressure and $t$ the time. As the measured profiles were closely logarithmic, the expression for the gradient $\mathrm{d} T / \mathrm{d} z$ is given by

$$
\frac{\mathrm{d} \mathcal{T}}{\mathrm{d} z}=\frac{k_{\mathrm{t}}}{z}
$$

where $k_{\mathrm{t}}=\Delta T / 2.3\left(\log z_{\mathrm{I}}-\log z_{2}\right)$, and a similar expression for $\mathrm{d} e / \mathrm{d} z$.

\begin{tabular}{|c|c|c|c|c|}
\hline \multirow[t]{2}{*}{ Flux } & \multicolumn{2}{|c|}{ Sensible } & \multicolumn{2}{|c|}{ Latent } \\
\hline & Ly d $^{-1}$ & $\mathrm{MJ} \mathrm{m}^{-2} \mathrm{~d}^{-1}$ & Ly d ${ }^{-1}$ & $\mathrm{MJ} \mathrm{m}^{-2} \mathrm{~d}^{-1}$ \\
\hline Total ( $\begin{array}{ll}\text { I } & \text { d) }\end{array}$ & $737 \cdot 3$ & 30.8 & 10.3 & 0.4 \\
\hline Daily average & 67.0 & 2.8 & 0.9 & 0.04 \\
\hline Maximum daily & I 58.9 & 6.6 & 33.9 & I. 4 \\
\hline Minimum daily & 14.7 & 0.6 & -71.1 & 3.0 \\
\hline
\end{tabular}

As the temperature near the surface was always colder than the temperature at greater heights, the sensible heat flux was found to be always positive. Positive latent heat flux (condensation) was found during $66 \%$ of the period, while during $34 \%$ of the time evaporation occurred. The mean and extreme daily eddy fluxes are given in Table V. 
(c) Heat flux in the ice and amount of ice melt

As the ice at the place of observation was below freezing point (about $-0.6^{\circ} \mathrm{C}$ at $\mathrm{I} \mathrm{m}$ depth), a small heat flux into the ice was observed. As the temperature profile measurements in the ice, which were originally recorded continuously, ceased, a mean value of $-2.9 \mathrm{Ly} \mathrm{d}^{-1}$ (o.12 $\mathrm{MJ} \mathrm{m}^{-2} \mathrm{~d}^{-1}$ ) was calculated from a spot measurement. However, even variations of this heat flux during the I I d of observation would not effect the heat balance as a whole substantially, as this heat flux is small.

The amount of ice melt has been discussed previously.

\section{(d) Heat balance as a whole}

The heat balance is shown diagrammatically on a daily basis in Figure 7, and in Table VI the components of the balance are shown as totals, mean day-time, mean night-time, and daily values; the percentage components of both sources and sinks are also given.

The balances are not achieved between the totals of components of sources and sinks. For the whole period a difference of $52.3 \mathrm{Ly}\left(2.17 \mathrm{MJ} \mathrm{m}^{-2}\right)$ is observed (Table VI). This

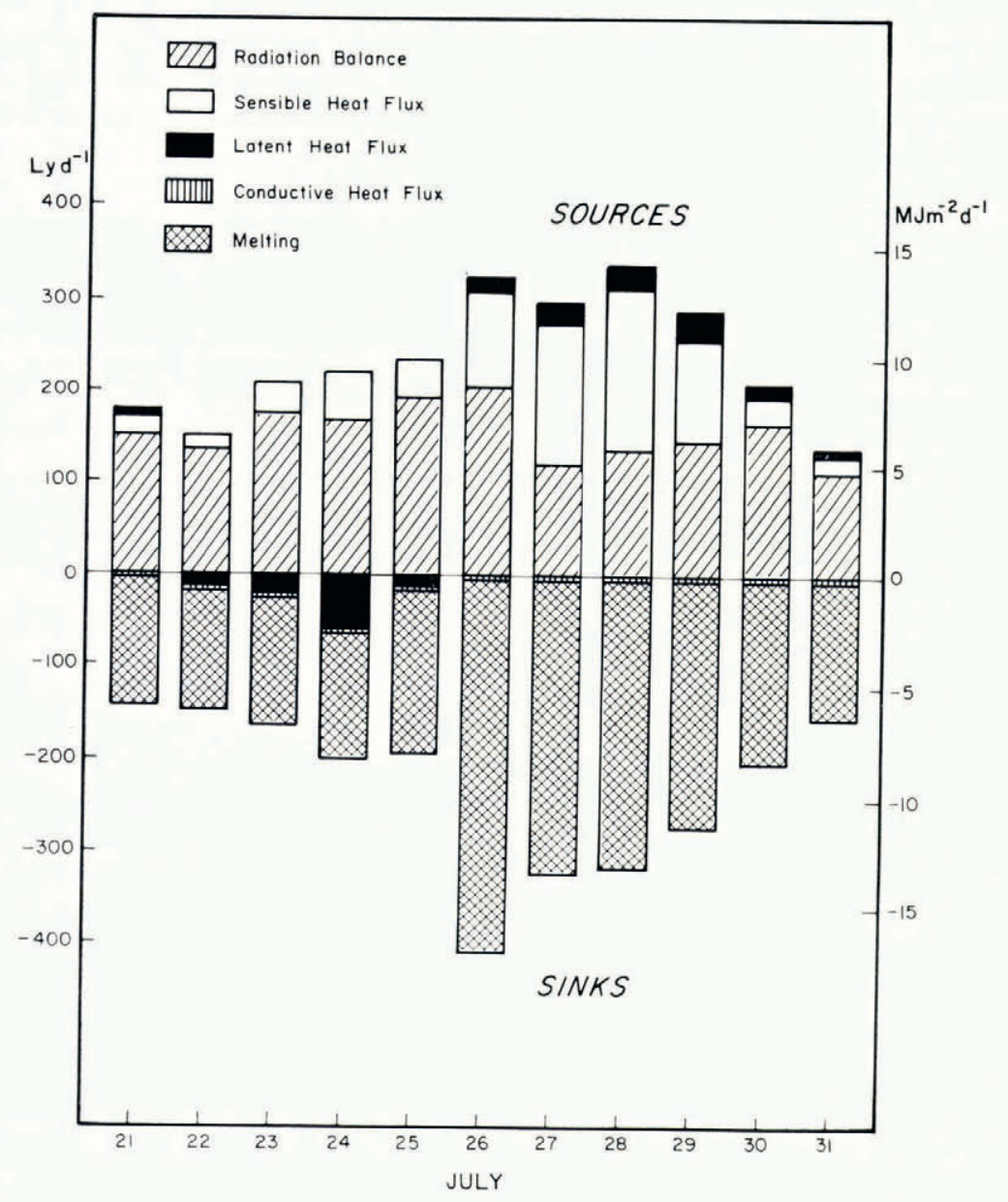

Fig. 7. Heat balance of McCall Glacier surface, 1972. 
represents a very good agreement; percentage-wise the agreement in the daily values is not as good (Fig. 7). However, considering the various sources of errors, the disagreement is not unreasonable.

Table VI. Components of the heat balance, McCall Glacier, 2 i July-i August $197^{2}$

\begin{tabular}{|c|c|c|c|c|c|c|c|c|c|}
\hline \multirow[t]{2}{*}{ Components } & \multicolumn{2}{|c|}{$\begin{array}{l}\text { Total period } \\
\qquad\left(\begin{array}{lll}\mathrm{I} & \mathrm{d}\end{array}\right)\end{array}$} & \multicolumn{2}{|c|}{$\begin{array}{c}\text { Average davtime } \\
(09 \mathrm{~h}-20 \mathrm{~h})\end{array}$} & \multicolumn{2}{|c|}{$\begin{array}{l}\text { Average nighttime } \\
\quad(20 \mathrm{~h}-09 \mathrm{~h})\end{array}$} & \multicolumn{2}{|c|}{ Average daily } & Per cent* \\
\hline & Ly & $\mathrm{MJ} \mathrm{m}^{-2}$ & Ly & $\mathrm{MJ} \mathrm{m}^{-2}$ & Ly & $\mathrm{MJ} \mathrm{m}^{-2}$ & $\operatorname{Lyd~}^{-1}$ & $\mathrm{MJ} \mathrm{m}^{-2} \mathrm{~d}^{-1}$ & $(\%)$ \\
\hline Radiation balance & I 717.1 & 71.77 & 135.5 & 5.66 & 20.6 & 0.86 & I56. I & $6.5^{2}$ & $69 \cdot 7$ \\
\hline Sensible heat flux & $737 \cdot 3$ & 30.82 & 29.5 & 1.23 & $37 \cdot 5$ & I. 57 & 67.0 & $2.8 \mathrm{o}$ & $29 \cdot 9$ \\
\hline Latent heat flux & 10.3 & 0.43 & 7.0 & 0.29 & -6.1 & -0.25 & 0.9 & 0.04 & 0.4 \\
\hline Heat flux in ice & $-31 \cdot 3$ & -1.31 & $-1 \cdot 3$ & -0.05 & -1.5 & -0.06 & -2.8 & -0.12 & -1.3 \\
\hline Ablation (stakes) & -2408.8 & -100.69 & $-\mathrm{I} 6 \mathrm{I} .3$ & -6.74 & -57.5 & -2.40 & -218.8 & -9.14 & -98.7 \\
\hline Total & 24.6 & 1.02 & $9 \cdot 4$ & 0.39 & -7.0 & -0.28 & 2.2 & O. IO & \\
\hline
\end{tabular}

* Total sources and total sinks are each assumed to total $100 \%$.

The percentage components of the heat balance for this study (radiation $68.9 \%$, sensible $30.3 \%$ and latent $0.8 \%$ ) are similar to the values found by LaChapelle (r959) for a period of $37 \mathrm{~d}$ on Blue Glacier in Washington, U.S.A. (lat. $47^{\circ} 5 \mathrm{o}^{\prime} \mathrm{N}$., long. $123^{\circ} 4 \mathrm{o}^{\prime} \mathrm{W}$.), who found the three heat balance components to be $69 \%, 25 \%$ and $6 \%$, respectively. Also Hoinkes (1955) found similar values in the Alps. In southern and south-eastern Alaska the importance of the radiation factor in ablation was found to be somewhat reduced (Streten and Wendler, I968; Wendler and Streten, 1969), owing to the higher air temperature and the reduced duration of sunshine as compared with McCall Glacier.

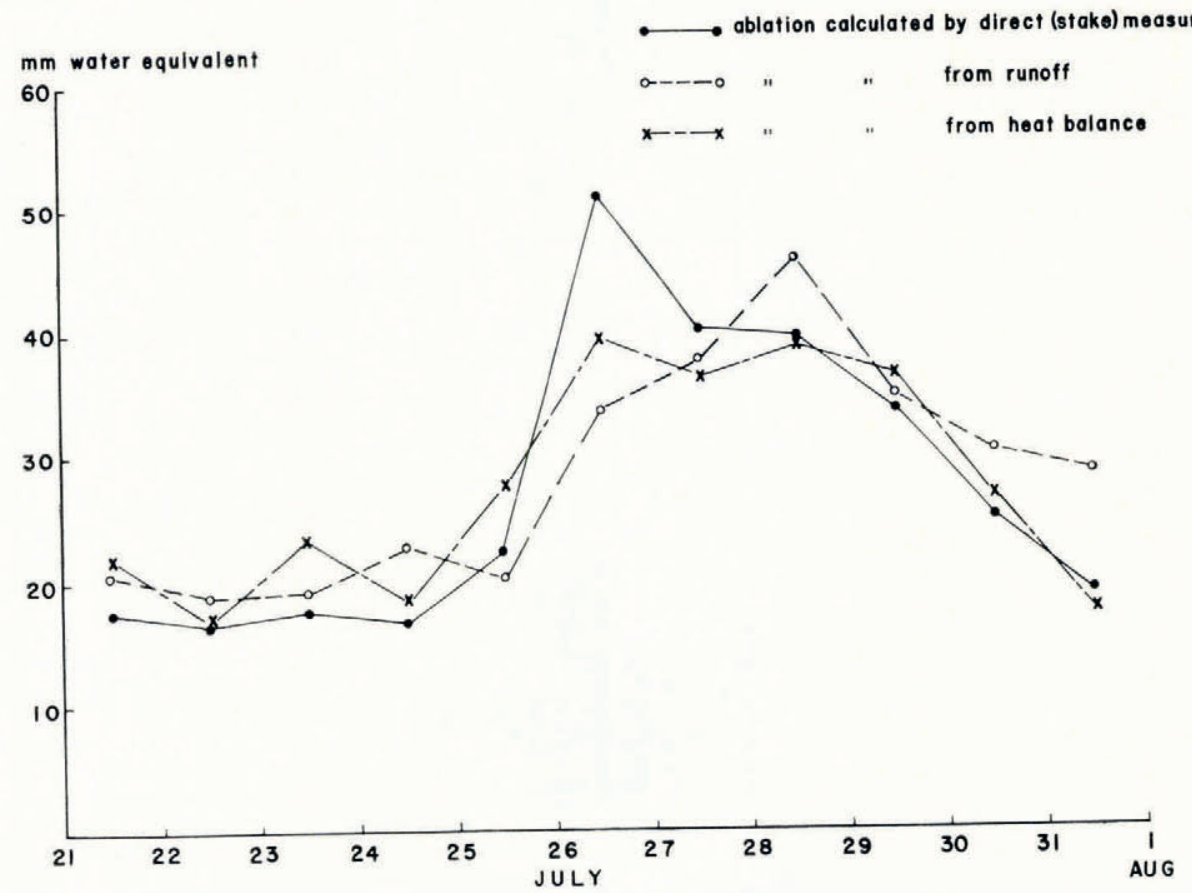

Fig. 8. Daily values of the amount of ice melt calculated by three different methods, McCall Glacier, 1972. 
Comparison of the three methods of obtaining the amount of ICE MELT

Comparisons of the combined water and ice balances for whole glaciers have been carried out previously (e.g. Meier and others, I97I; Wendler and others, in press). In our case, the comparison is done in three different ways for this small controlled area: (a) stake, (b) run-off and (c) as the remainder of heat-balance calculations. The daily values of the amount of ice melt are given in Figure 8, which shows that the agreement for daily values is not in all cases perfect. This may be partly caused by inaccuracies in the direct stake measurements, as, due to internal ablation, the correct daily amount of ice ablation is not always obtained. In Table VII the comparison is done for the whole period, and for an average day and night. The agreement here is very satisfactory. The amount of ice melt calculated from the run-off and heat-balance calculations gives $3.5 \%$ and $1.2 \%$ higher values, respectively, than the direct stake measurements. For the mean days and nights the disagreement is somewhat larger.

Table VII. Comparison with ablations of three DifFerent measurements

\begin{tabular}{|c|c|c|c|}
\hline & $\begin{array}{l}\text { Ablation from direct } \\
\text { measurement (stake) }\end{array}$ & $\begin{array}{c}\text { Ablation from run-off } \\
\text { measurement }\end{array}$ & $\begin{array}{l}\text { Ablation from heat } \\
\text { balance measurement }\end{array}$ \\
\hline Daily mean for day-time (og $\mathrm{h}-20 \mathrm{~h}$ ) & $\begin{array}{c}\mathrm{mm} \text { water equivalent } \\
20 . \mathrm{I}\end{array}$ & $\begin{array}{c}\mathrm{mm} \text { water equivalent } \\
2 \mathrm{I} \cdot 4\end{array}$ & $\begin{array}{c}\mathrm{mm} \text { water equivalent } \\
2 \mathrm{I} .4\end{array}$ \\
\hline Daily mean for night-time $(20 \mathrm{~h}-09 \mathrm{~h})$ & 7.2 & $\begin{array}{r}21.4 \\
6.9\end{array}$ & $\begin{array}{r}21.4 \\
6.3\end{array}$ \\
\hline Sum for i i d & 300.7 & 311.2 & 304.2 \\
\hline
\end{tabular}

\section{Conclunsion}

It has been shown that satisfactory agreement of results is achieved when ice ablation is measured in three different ways. This is encouraging for it suggests that it may be possible to calculate the combined ice, water and heat balance for the glacier as a whole. Kojima and others ( I 97I) have carried out such work for a snow field in Japan, but the analyses became much more complex and agreement was not found to be as good. When the drainage area is larger, greater lag time with changes in the amount of liquid storage in the basin is observed, and furthermore, it is normally not possible to work with only one heat-balance station, as differences between a valley and hill station may be very big (Kojima and others, I97I; Wendler, I97 I ; Ishikawa and Ishida, 1972).

\section{Acknowledgements}

The research was supported by the Atmospheric Sciences Section, National Science Foundation, under Grant GA-288278x; logistic support was given by the Air National Guard, Anchorage, Alaska. The authors thank Dr B. Holmgren who revised this manuscript and made many valuable comments. Mr D. Kane, Institute of Water Resources, University of Alaska, made the water-level recorder available to us, for which we are grateful.

\section{MS. received II October 1972}

\section{REFERENCES}

Ambach, W. 1963. Untersuchungen zum Energieumsatz in der Ablationszone des Grönländischen Inlandeises. (Camp IV-EGIG, $69^{\circ} 40^{\prime}$ o5" N, $49^{\circ} 37^{\prime} 5^{\prime \prime \prime} \mathrm{W}$ ). Meddelelser om Gronland, Bd. 1 74, Nr. 4.

Derikx, A. L. In press. The heat balance and associated run-off from an experimental site on the glacier tongue. [Paper presented at the International Union of Geodesy and Geophysics XV General Assembly, Moscow, 30 July-14 August 1971.]

Dirmhirn, I., and Trojer, E. 1955. Albedountersuchungen auf dem Hintereisferner. Archiv für Meteorologie, Geophysik und Bioklimatologie, Ser. B, Bd. 6, Ht. 4, p. 400-16. 
Hoinkes, H. C. 1953. Wärmeumsatz und Ablation auf Alpengletschern. II. Hornkees (Zillertaler Alpen), September i951. Geografiska Annaler, Årg. 35, Ht. 2, p. I i6-40.

Hoinkes, H. C. 1955. Measurements of ablation and heat balance on Alpine glaciers. Fournal of Glaciology, Vol. 2,

No. I7, p. 497-501.
Holmgren, B. 1971. Climate and energy exchange on a sub-polar ice cap in summer. Arctic Institute of North America Devon Island Expedition $196 \mathrm{r}-\mathrm{r} 963$. Part E. Radiation climate. Meddelanden frän Uppsala Universitets Meteorologiska Institution, Nr. $1 \mathrm{I}$ I.

Ishikawa, N., and Ishida, T. In press. Observations of radiative cooling at basins in midwinter and snow-melting season. Fournal of the Meteorological Society of Japan.

Keeler, C. M. 1957. Ablation studies: lower McCall Glacier, June 23-September 1, 1957. I.G.Y. Glaciological Report Series, No. I, p. XII-I I-XII-I 5 .

Kojima, K., and others. 1971. Moshiri no koryūiki ni okeru yūsetsu, ryūshitsu oyobi netsu-shūshi no kenkyū. II [Studies of snow melt, run-off and heat balance in a small drainage area in Moshiri, Hokkaido. II]. [By] K. Kojima, D. Kobayashi, H. Aburakawa, R. Naruse, K. Ishimoto, N. Ishikawa [and] S. Takahashi. Teionkagaku: Low Temperature Science, Ser. A, [No.] 29, p. 159-76.

LaChapelle, E. R. 1959. Annual mass and energy exchange on the Blue Glacier. Fournal of Geophysical Research, Vol. 64, No. 4, p. $443-49$.

Lang, H. 1968. Relations between glacier runoff and meteorological factors observed on and outside the glacier. Union de Géodésie et Géophysique Internationale. Association Internationale d'Hydrologie Scientifique. Assemblée générale de Berne, 25 sept. -7 oct. 1967. [Commission de Neiges et Glaces.] Rapports et discussions, p. 429-39.

Lettau, H. 1939. Atmosphärische Turbulenz. Leipzig, Akademische Verlagsgesellschaft.

Lettau, H. 1949. Isotropic and non-isotropic turbulence in the atmospheric surface layer. Bedford, Mass., Geophysics Research Directorate, U.S. Air Force Cambridge Research Center. (Geophysical Research Papers, No. r.)

Meier, M. F., and Tangborn, W. V. I96r. Distinctive characteristics of glacier runoff. U.S. Geological Survey. Professional Paper 424-B, p. B-14-B-16.

Meier, M. F., and others. I971. Ice and water balances at selected glaciers in the United States. Combined ice and water balances of Gulkana and Wolverine glaciers, Alaska, and South Cascade Glacier, Washington, 1965 and 1966 hydrologic years, by M. F. Meier, W. V. Tangborn, L. R. Mayo and A. [S.] Post. U.S. Geological Survey. Professional Paper 715-A.

Orvig, S., ed. I961. McCall Glacier, Alaska: meteorological observations, 1957-1958. Arctic Institute of North America. Research Paper No. 8.

Orvig, S., and Mason, R. W. I $_{6} 6_{3}$. Ice temperatures and heat flux, McCall Glacier, Alaska. Union Géodésique et Géophysique Internationale. Association Internationale d'Hydrologie Scientifique. Assemblée générale de Berkeley, 19-8$31-81963$. Commission des Neiges et des Glaces, p. $181-88$.

Prandt, L. I956. Führer durch die Strömungslehre. 4. Auflage. Braunschweig, F. Vieweg und Sohn.

Searby, H. W. 1968. Climates of the States. Alaska. Washington, D.C., U.S. Weather Bureau. (Climatology of the United States, 6o-49.)

Streten, N. A., and Wendler, G. 1968. The midsummer heat balance of an Alaskan maritime glacier. Journal of Glaciology, Vol. 7, No. 51, p. 431-40.

Sverdrup, H. W. I936. The eddy conductivity of the air over a smooth snowfield. Results of the NorwegianSwedish Spitsbergen Expedition in 1934. Geofysiske Publikasjoner, Vol. I I, No. 7.

Untersteiner, N. 1957. Glazial-meteorologische Untersuchungen im Karakorum. II. Wärmehaushalt. Archiv

für Meteorologie, Geophysik und Bioklimatologie, Ser. B, Bd. 8, Ht. 2, p. 137-71.
Wendler, G. 1971. An estimate of the heat balance of a valley and hill station in central Alaska. Journal of Applied Meteorology, Vol. io, No. 4, p. 684-93.

Wendler, G., and Streten, N. A. 1969. A short term heat balance study on a Coast Range glacier. Pure and Applied Geophysics, Vol. 77, No. 6, p. 68-77.

Wendler, G., and others. 1972. Mass balance studies on McCall Glacier, Brooks Range, Alaska, [by] G. Wendler, C. Fahl and S. Corbin. Arctic and Alpine Research, Vol. 4, No. 3, p. 2 I I-22.

Wendler, G., and others. In press. On the hydrology of a partly glacier-covered Arctic watershed, by G. Wendler, D. Trabant and C. [S.] Benson. [Paper presented at International Symposia on the Role of Snow and Ice in Hydrology, Banff, Canada, UNESCO Session 4, 8 September 1972.]

Yosida, Z. 1960. Nissha ni yoru sekisetsu no naibu yūkai [Internal melting of snow due to the penetrating sunlight]. Teion-kagaku: Low Temperature Science, Ser. A, [No.] 19, p. 97-1 Io. 